\title{
Echinococcus granulosus hydatid cyst location is modified by Fasciola hepatica infection in cattle
}

\author{
Caroll Stoore ${ }^{1}$, Constanza Andrade ${ }^{1}$, Christian Hidalgo ${ }^{1}$, Felipe Corrêa ${ }^{1}$, Mauricio Jiménez ${ }^{1}$, \\ Marcela Hernandez ${ }^{2,3}$ and Rodolfo Paredes ${ }^{1 *}$ (D)
}

\begin{abstract}
Background: Natural parasite infection occurs in wild and domestics animals with more than one parasite species at the same time, generating an infection called polyparasitism. Cystic echinococcosis reports are usually based only on infection with Echinoccocus granulosus leaving aside other internal parasitoses that could modulate both the immune response and pathogenesis of the natural infection. Fasciola hepatica is another cosmopolitan parasite in ruminants with a similar distribution to $E$. granulosus in different parts of the world, but no information of the effect of co-infection with E. granulosus has been described. The aims of this report were to establish E. granulosus prevalence and explore the association of F. hepatica co-infection and natural E. granulosus infections in cattle.

Results: From 1725 animals, the prevalence of E. granulosus and F. hepatica was 21.16 and $51.3 \%$, respectively. Considering both infections, older cattle (> 4 years) presented higher prevalence compared to younger animals. In E. granulosus-infected cattle, 5.21\% had fertile cysts, 71.78\% infertile cysts, and in 23.01\% cysts were smaller than 1 $\mathrm{cm}$ in diameter. Considering cyst location, 39.72\% had lungs cysts, $24.72 \%$ had liver cysts and $36.94 \%$ had cysts in both organs. Cyst location significantly differed between age groups: $44.68 \%$ of younger animals had cysts only in the lungs, while older animals presented hydatid cyst in the lungs and liver simultaneously (44.15\%). With $E$. granulosus infection alone, $30.26 \%$ of cysts were found in the lungs, $31.79 \%$ in the liver and $37.95 \%$ in both organs. Regarding the co-infection of E. granulosus with $F$. hepatica, the proportion was significantly different $(P<0.05)$ with most animals having cysts only in the lungs (49.41\%) and a lower level of liver infection (15.88\%). Analyzing organ cyst distribution and F. hepatica absence/presence ratio within each cyst type, small cysts showed the highest difference in ratio.
\end{abstract}

Conclusions: To the best of our knowledge, this is the first report indicating that F. hepatica co-infection in cattle could be affecting the instate of hydatid cysts in the liver, displacing toward lung localization, suggesting an antagonistic relationship.

Keywords: Echinococcus granulosus, Fasciola hepatica, Polyparasitism, Hydatid cyst localization

\section{Background}

Co-infection with different parasite species in the same host (also known as polyparasitism) is a well-documented fact in medical, veterinary and zoological literature. Most of the animals that live in the wild and humans of rural areas can be hosts of many concurrent parasite species [1]. However,

\footnotetext{
* Correspondence: rparedes@unab.cl

${ }^{1}$ Escuela de Medicina Veterinaria, Facultad de Ciencias de la Vida, Universidad Andres Bello, Santiago, Chile

Full list of author information is available at the end of the article
}

the synergistic or antagonic relationship that different parasite species can have within the same host remains poorly studied [2]. Helminth parasites are a very diverse group of animals that are classified in four taxonomic groups: nematodes, trematodes, cestodes and acanthocephalans [3]. In cattle, two parasites usually represent a frequent infection: the cestode E. granulosus (sensu lato) and the trematode $F$. hepatica. Echinococcus granulosus (s.l.) has an indirect life-cycle, with ruminants as intermediate hosts, dogs and other canids as definitive hosts, and humans as dead-end

(c) The Author(s). 2018 Open Access This article is distributed under the terms of the Creative Commons Attribution 4.0 International License (http://creativecommons.org/licenses/by/4.0/), which permits unrestricted use, distribution, and 
hosts [4]. The metacestode stage called hydatid cysts develops in the viscera (mainly lungs and liver) of the intermediate hosts [5], causing a disease known as cystic echinococcosis. Fasciola hepatica also has an indirect life-cycle; however, herbivores act as the definitive hosts, with the adult worms located in the bile ducts [6].

Echinococcus granulosus (s.l.) is composed of E. granulosus (sensu stricto) (genotypes G1-3), E. equinus (genotype G4), E. ortleppi (genotype G5), E. canadensis (genotypes G6-8/G10) and E. felidis ("lion strain"), with E. granulosus (s.s.) being the most commonly distributed worldwide [7].

Although E. granulosus (s.l.) is able to infect a wide range of mammalian hosts, the metacestode stage has a different capacity to produce protoscoleces, the stage infective to the definitive host. For unknown reasons, the parasite can, in some animals, produce protoscoleces inside the cyst, generating a fertile hydatid cyst, but other animals with cystic echonococcosis possess cysts without protoscoleces called infertile hydatid cysts $[8,9]$. Since cyst fertility is associated with the size of the hydatid cyst [4], there is a subset of hydatid cysts that are too small to be classified as either fertile or infertile. The cellular and molecular mechanisms involved in the process of cyst fertility remain unknown [10]. In cattle, hydatid cyst fertility status ranges from 0 to $96 \%$ in different parts of the world [11-22] and infection with $F$. hepatica is common in many parts of the world. However, there are no studies on relationships between E. granulosus (s.l.) and F. hepatica in co-infections.

Although belonging to different higher-level flatworm taxa, both parasites exhibit common traits regarding their interaction with the mammalian host; as such, serum of animals infected experimentally with E. granulosus (s.l.) can recognize $F$. gigantica antigens in immunoassays [23] but there are no specific data on cross-reaction with $F$. hepatica. However, both parasites have the ability to uptake host glycolipids [6] which could explain the latter. Reports of polyparasitism involving E. granulosus (s.l.) are scarce. There is only one report that includes the interaction with Schistosoma mansoni (a trematode), where in murine models simultaneous concomitant infection lead to higher IFN- $\gamma$ profiles, displaying a $\mathrm{T}_{\mathrm{H}} 1$ response; however, adding E. granulosus infection seven weeks after $S$. mansoni infection led to significant lower IL-10 production, changing the immune profile to a $\mathrm{T}_{\mathrm{H}} 2$ response [24]. Here, we provide the first report that in bovines infected with $E$. granulosus (s.l.), the presence of co-infection with $F$. hepatica is associated with changes in the hydatid cysts localization.

\section{Methods}

\section{Sampling design}

A total of 1725 cattle were examined for the presence of hydatid cyst and $F$. hepatica infection at post-mortem inspection in a Region Metropolitana slaughterhouse, Chile.
In routine slaughtering, animals were individually identified, age and sex was recorded, and visceral organs of each animal, mainly the lungs and liver, were visually examined, palpated and incised along with official veterinarian inspectors for the presence of hydatid cysts and F. hepatica.

Fasciola hepatica diagnosis was made either by direct visualization of adult parasites in bile ducts, or by $F$. hepatica compatible lesions such as enlarged and thickened bile ducts, calcification of bile ducts, black parasitic material and black lymph nodes in the liver: signs of chronic F. hepatica infection.

Suspected cystic samples were removed from the infected organ, placed in separate polythene bags and transported in an isothermal container within $3 \mathrm{~h}$ to Universidad Andres Bello Veterinary School for further examination. For hydatid cysts confirmation and fertility determination, cysts were microscopically examined as previously described [25]. Echinococcus granulosus (s.l.) genotyping in hydatid cyst samples was determined as previously reported [26]. Briefly, DNA was extracted from fertile, infertile and small hydatid cysts from both livers and lungs. The cox $1 \mathrm{mtDNA}$ was amplified and sequenced, and a 345-nucleotide consensus sequence was used for comparison analysis.

\section{Study groups}

Animals were classified according to their age, hydatid cyst type and location. By age range, individuals were divided into two groups: 4 years-old or younger ( $\leq 4$ years) and over 4 years of age ( $>4$ years). Cysts were classified into 3 types: small cysts $(<1 \mathrm{~cm}$ in diameter $)$; fertile cysts (with protoscoleces); and infertile cysts $(>1 \mathrm{~cm}$ in diameter and without protoscoleces). Animals were also separated into 3 groups according to the location of the hydatid cysts: in lungs only; in liver only; and in both organs simultaneously. All groups were also separated by their $F$. hepatica co-infection status.

\section{Data analysis}

Data were recorded in an Excel 2010 datasheet and analyzed with RStudio IDE version 1.0.136 and R version 3.3.3 for statistical associations among variables using a Chi-square test. Logistic regressions were performed using STATA v.12 software (StataCorp, College Station, TX, USA). Statistical significance was considered when $P$-values were below the 0.05 threshold.

\section{Results}

Prevalence of E. granulosus and F. hepatica

Of the animals examined, 1217 were 4 years of age or under, and 508 were over 4 years-old. The overall prevalence of $E$. granulosus and F. hepatica was $21.16 \%$ (95\% CI: $19.25-$ 23.16\%) and 51.3\% (95\% CI: 48.92-53.69\%), respectively. For both parasites, older cattle ( $>4$ years-old) had a significantly 


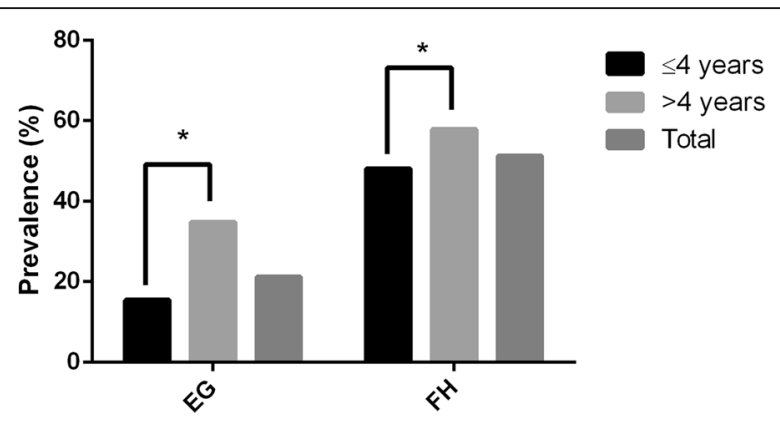

Fig. 1 Echinococcus granulosus (EG) and Fasciola hepatica (FH) overall prevalence per age group in inspected cattle $(n=1725)$. Data shown as percentage of infected/ total examined cattle in the respective categories. ${ }^{*} P<0.05$ (Chi-square test)

higher prevalence than younger animals $(\leq 4$ years-old) $(E$. granulosus: $\chi^{2}=80.81, d f=1, P<0.0001 ;$ F. hepatica: $\chi^{2}=$ 12.56, $d f=1, P=0.0002$ ) (Fig. 1). Separating co-infected animals, which represented $9.86 \%(n=170)$ of the sampled population, E. granulosus-only infected cattle $(n=195$, 11.3\%) remains higher in older animals $\left(\chi^{2}=22.72, d f=1\right.$, $P<0.0001)$, as in co-infected cattle $\left(\chi^{2}=52.63, d f=1\right.$, $P<0.0001)$, but not in animals with $F$. hepatica-only infection $(n=715,41.45 \%)$ where no significant difference between age groups was found $\left(\chi^{2}=0.4273\right.$, $d f=1, P=0.5133$ ) (Table 1 ).

\section{Hydatid cyst type, location and genotype}

In E. granulosus-infected cattle, 5.21\% $(n=19)$ had fertile cysts, $71.78 \%(n=262)$ had infertile cysts, and in $23.01 \%$ $(n=84)$ cysts were smaller than $1 \mathrm{~cm}$ in diameter. Considering cyst location, 143 animals (39.72\%) had cysts only in the lungs, 89 (24.72\%) had cysts in the liver only and 133 (36.94\%) had cysts in both organs simultaneously. A statistically significant difference was found regarding the location and type of the cysts $\left(\chi^{2}=66.32, d f=4, P<0.0001\right)$. The majority of the animals with fertile cysts had these located in the lungs only (68.42\%) whereas the majority of infertile cysts were located in both organs and small cysts were mainly located in the liver (Table 2). Of the recovered hydatid cyst samples, $47.95 \%(n=175)$ were genotyped. Of these, $98.86 \%(n=173)$ were identified as $E$. granulosus (s.s.) and only $1.14 \%(n=2)$ were identified as E. ortleppi.

\section{Association of hydatid cyst characteristics with animal} age and co-infection with $F$. hepatica

As shown in Fig. 2a, hydatid cyst location significantly differed between age groups $\left(\chi^{2}=16.30, d f=2, P=0.0003\right)$, where the highest percentage of younger animals had cysts only in the lungs (44.68\%) while the largest portion of older animals had cysts in the liver and lungs simultaneously (44.15\%). Hydatid cyst in animals lacking F. hepatica were present in only the lungs of $30.26 \%$ of infected cattle, $31.79 \%$ had the cysts in the liver only and $37.95 \%$ in both organs. However, in the presence of concomitant $F$. hepatica infection, the proportion was significantly different $\left(\chi^{2}=18.20, d f\right.$ $=2, P=0.0001$ ) with a higher percentage of animals with cysts only in the lungs (49.41\%) and a lower percentage with hydatid cysts only in the liver $(15.88 \%)$ and $34.71 \%$ of animals with both organs simultaneously affected (Fig. 2b). Within animals lacking $F$. hepatica co-infection, no association between location and age group $\left(\chi^{2}=5.065, d f=2, P=0.0795\right)$ or significant variation within each age group was observed ( $\leq 4$ years: $\chi^{2}=0.1800, d f=2, P=0.9139 ;>4$ years: $\chi^{2}=5.070, d f=2, P=0.0793$ ) (Fig. 2c). However, in co-infected animals, cyst location was associated with age $\left(\chi^{2}=14.16, d f=2, P=0.0008\right)$ and varied within each age group $\left(\leq 4\right.$ years: $\chi^{2}=15.38, d f=2, P=0.0005 ;>4$ years: $\chi^{2}=17.24, d f=2, P=0.0002$ ) (Fig. $2 d$ ). Specifically, in E. granulosus (s.s.)-infected animals, cyst location also significantly varied with $F$. hepatica co-infection $\left(\chi^{2}=\right.$ 6.841, $d f=2, P=0.0327)$ but not with age $\left(\chi^{2}=5.674, d f=\right.$ $2, P=0.0586)$. Location in host varied only in animals co-infected with $F$. hepatica $\left(\chi^{2}=6.209, d f=2, P=0.0448\right)$ (Table 3).

No general association was found between cyst type and the age range of animals $\left(\chi^{2}=1.452, d f=2, P=0.4838\right)$ or co-infection with $F$. hepatica $\left(\chi^{2}=1.64, d f=2, P=0.4405\right)$. Conversely, the co-infection ratio (absence/presence of $F$. hepatica co-infection) of animals with infertile cysts was significantly higher in young animals $(1.14,76 / 54)$ than in older cattle $(0.81,59 / 73)\left(\chi^{2}=4.968, d f=1, P=0.0258\right)$, while in the latter group there were fewer animals with small $(<1 \mathrm{~cm})$ cysts in the presence of the co-infection than in the absence (24/12), resulting in a statistical association between cyst type and co-infection in this age group $\left(\chi^{2}=\right.$ 6.349, $d f=2, P=0.0418)$. In animals with small hydatid cysts, E. granulosus-affected organs significantly varied with F. hepatica co-infection $\left(\chi^{2}=19.45, d f=2, P<0.0001\right)$,

Table 1 Echinococcus granulosus, Fasciola hepatica and co-infection prevalence, per age range classification of slaughtered cattle

\begin{tabular}{|c|c|c|c|c|c|c|c|c|c|c|}
\hline & \multirow{2}{*}{$\begin{array}{l}\text { Examined } \\
N\end{array}$} & \multicolumn{3}{|c|}{ EG only } & \multicolumn{3}{|c|}{ FH only } & \multicolumn{3}{|c|}{ EG and FH co-infected } \\
\hline & & $n$ & $\%$ & $95 \% \mathrm{Cl}$ & $n$ & $\%$ & $95 \% \mathrm{Cl}$ & $n$ & $\%$ & $95 \% \mathrm{Cl}$ \\
\hline Overall & 1725 & 195 & 11.30 & $9.90-12.89$ & 715 & 41.45 & $39.15-43.79$ & 170 & 9.86 & $8.54-11.35$ \\
\hline$\leq 4$ years & 1217 & 109 & 8.96 & $7.48-10.69$ & 507 & 41.66 & $38.92-44.45$ & 79 & 6.49 & $5.24-8.02$ \\
\hline$>4$ years & 508 & 86 & 16.93 & $13.92-20.44$ & 203 & 39.96 & $35.79-44.28$ & 91 & 17.91 & $14.82-21.48$ \\
\hline
\end{tabular}

Abbreviations: FH Fasciola hepatica, EG Echinococcus granulosus, N/n number of animals by category, \%, percentage of infection(s) positive animals of the total of animals examined by category 
Table 2 Frequency and percentage of organ localization according to cyst type

\begin{tabular}{lllll}
\hline Cyst type & $N$ & $\begin{array}{l}\text { Lungs only } \\
n(\%)\end{array}$ & $\begin{array}{l}\text { Liver only } \\
n(\%)\end{array}$ & $\begin{array}{l}\text { Both } \\
n(\%)\end{array}$ \\
\hline Infertile & 262 & $107(40.84)$ & $40(15.27)$ & $115(43.89)$ \\
Fertile & 19 & $13(68.42)$ & $2(10.53)$ & $4(21.05)$ \\
Small & 84 & $23(27.38)$ & $47(55.95)$ & $14(16.67)$ \\
Total & 365 & $143(39.18)$ & $89(24.39)$ & $133(36.44)$
\end{tabular}

Abbreviation: $N / n$ number of animals where the ratio in lungs, liver and both organs was 0.28 (5/ 18), 3.27 (36/11) and $1.8(9 / 5)$, respectively (Table 4$)$.

Logistic regression analysis revealed a statistically significant association between the localization of the hydatid cysts and the presence of $F$. hepatica co-infection in both, bivariate and multivariate models (Table 5). In animals with $F$. hepatica co-infection, hydatid cyst were less likely to localize in the liver than lungs, while this association remained similar in the adjusted model (OR $=0.31, P<0.0001$, bivariate; $\mathrm{OR}=0.36, P=0.027$, adjusted model).

\section{Discussion}

The prevalence of E. granulosus and F. hepatica in the present study is consistent with the official national

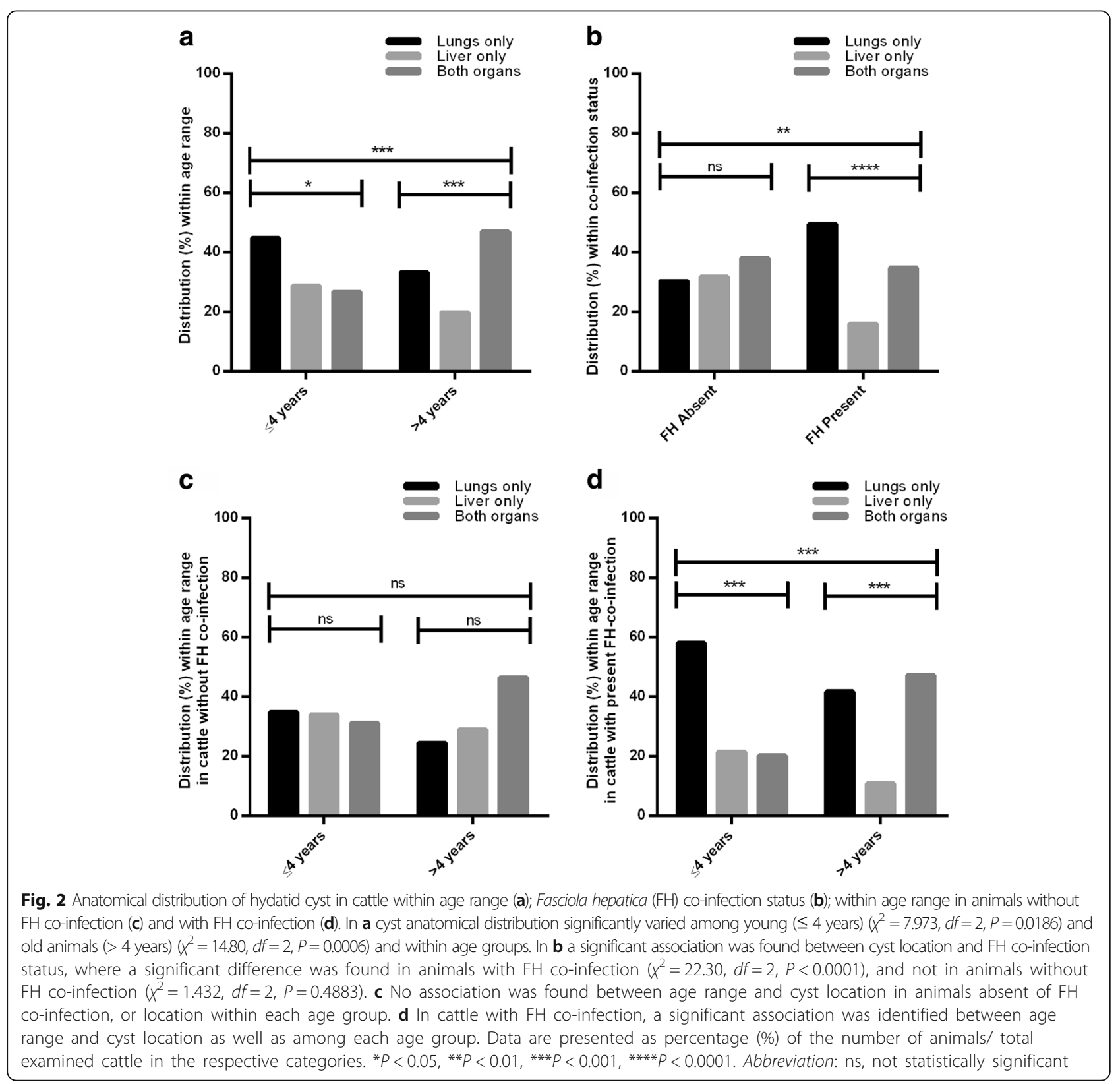


Table 3 Hydatid cyst anatomical location within age range and Fasciola hepatica co-infection in E. granulosus (s.s.)-infected animals

\begin{tabular}{|c|c|c|c|c|c|c|}
\hline FH-EG co-infection & Host age range & $\begin{array}{l}\text { Lungs only } \\
n(\%)\end{array}$ & $\begin{array}{l}\text { Liver only } \\
n(\%)\end{array}$ & $\begin{array}{l}\text { Both organs } \\
n(\%)\end{array}$ & $x^{2}$ & $P$ \\
\hline \multirow[t]{3}{*}{ Absent } & $\leq 4$ years & $17(32.69)$ & $14(26.92)$ & $21(40.38)$ & 0.6903 & 0.7081 \\
\hline & $>4$ years & $10(37.04)$ & $5(18.52)$ & $12(44.44)$ & & \\
\hline & Total $^{a}$ & $27(34.18)$ & $19(24.05)$ & $33(41.77)$ & & \\
\hline \multirow[t]{3}{*}{ Present } & $\leq 4$ years & $24(55.81)$ & $7(16.28)$ & $12(27.91)$ & 6.209 & $0.0448^{*}$ \\
\hline & $>4$ years & $22(43.14)$ & $3(5.88)$ & $26(50.98)$ & & \\
\hline & Total $^{\mathrm{a}}$ & 46 (48.94) & $10(10.64)$ & $38(40.43)$ & & \\
\hline \multirow[t]{3}{*}{ Total } & $\leq 4$ years & $41(43.16)$ & $21(22.11)$ & $33(34.74)$ & 5.674 & 0.0586 \\
\hline & $>4$ years & $32(41.03)$ & $8(10.26)$ & $38(48.72)$ & & \\
\hline & Total & $73(42.20)$ & $29(16.76)$ & $71(41.04)$ & & \\
\hline
\end{tabular}

*Statistically significant difference at $P<0.05$

${ }^{\text {a }}$ Statistically significant association of cyst location and co-infection $\left(X^{2}=6.841, P=0.0327\right)$

Abbreviations: EG E. granulosus (s.s.), FH Fasciola hepatica

slaughter and condemnation data at abattoirs. The prevalence of $E$. granulosus infection has remained steady since 1995; however, F. hepatica infection has increased [27, 28]. Older animals had a higher prevalence of E. granulosus infection, as reported in other studies $[11,29,30]$, and this prevalence in older animals remains regardless of $F$. hepatica co-infection. This could be due to an increase in time in which the animal can be exposed to E. granulosus [31]. For the prevalence of F. hepatica however, a difference was found only when $E$. granulosus-infected animals were included; no association was found between age and the proportion of animals infected. Innocent et al. [32] found an increase of liver condemnation due to $F$. hepatica in older cattle; however, the group studied had no animals over 30 months of age and disease prevalence was considerably lower [32].

The location of hydatid cysts varies among studies. In our study, most of the animals had hydatid cysts in their lungs as reported by some studies [14, 29, 33, 34]; however in others, liver was the most commonly affected organ $[11,18,35]$. A recent study in Chile, found that the proportion of organs infected with E. granulosus varied among geographical locations [36]. These authors have shown that of the genotyped cysts, belonging to $47.95 \%$ of E. granulosus-infected animals, most were identified as E. granulosus (s.s.) as has previously been reported in cattle in Chile [26]; this species is also the most common worldwide [37].

We found that hydatid cysts organ distribution varied with age, a factor not previously considered. Conversely, separating by co-infection with $F$. hepatica, a difference was found only in F. hepatica co-infected animals, where the proportion of animals with cysts in both liver and lungs was higher in older co-infected animals when compared with younger co-infected animals. As has been reported, older animals could have a higher number of cysts as exposure time is increased [31], which could also increase the number of organs affected.

Anatomical location was associated with co-infection status, with a decrease in liver-affected animals and an increase in lung-only-affected animals. In E. granulosus, portal circulation has been described as the primary route of infection by oncospheres, with a high tropism for the liver [38]. As F. hepatica in acute and chronic infections can damage the liver [39], it could be interfering with the establishment of E. granulosus in this organ. In the absence of $F$. hepatica, small hydatid cysts were

Table 4 Associations between hydatid cyst with or without Fasciola hepatica co-infection and host variables: age range and cyst location

\begin{tabular}{|c|c|c|c|c|c|c|c|c|c|c|c|c|}
\hline \multirow[t]{2}{*}{ Co-infection } & \multicolumn{4}{|c|}{ Fertile } & \multicolumn{4}{|c|}{ Infertile } & \multicolumn{4}{|c|}{$<1 \mathrm{~cm}$ diameter } \\
\hline & $(-/+)$ & Ratio & $x^{2}$ & $P$ & $(-/+)$ & Ratio & $x^{2}$ & $P$ & $(-/+)$ & Ratio & $x^{2}$ & $P$ \\
\hline$\leq 4$ years & $7 / 3$ & 2.33 & 2.554 & 0.11 & $76 / 54$ & 1.41 & 4.968 & $0.0258^{*}$ & $26 / 22$ & 1.18 & 13.341 & 0.2481 \\
\hline$>4$ years $^{\mathrm{a}}$ & $3 / 6$ & 0.5 & & & $59 / 73$ & 0.81 & & & $24 / 12$ & 2 & & \\
\hline Lungs only & $7 / 6$ & 1.17 & b & & $47 / 60$ & 0.78 & 4.409 & 0.1103 & $5 / 18$ & 0.28 & 19.45 & $<0.0001^{*}$ \\
\hline Liver only & $2 / 0$ & - & & & $24 / 16$ & 1.63 & & & $36 / 11$ & 3.27 & & \\
\hline Both organs & $1 / 3$ & 0.33 & & & $64 / 51$ & 1.25 & & & $9 / 5$ & 1.8 & & \\
\hline
\end{tabular}

*Statistically significant difference at $P<0.05$

${ }^{a}$ Statistically significant association between cysts type and co-infection in this group $\left(X^{2}=6.349, P=0.0418\right)$

${ }^{\mathrm{b}} n$ too small for statistical analyses

Abbreviations: $(-/+)$ number of animals without $F$. hepatica co-infection/number of animals with $F$. hepatica co-infection 
Table 5 Association between hydatid cyst location in liver and the presence of Fasciola hepatica co-infection

\begin{tabular}{llll}
\hline Variable & OR $(95 \% \mathrm{Cl})$ & $Z$ & $P$ \\
\hline Co-infection $^{\mathrm{a}}$ & $0.31(0.18-0.54)$ & -4.14 & $<0.0001$ \\
Co-infection $^{\mathrm{b}}$ & $0.36(0.15-0.90)$ & -2.21 & 0.027 \\
\hline
\end{tabular}

${ }^{a}$ Crude model (hydatid cyst location in liver versus Fasciola hepatica co-infection)

${ }^{b}$ Hydatid cyst location in liver versus Fasciola hepatica coinfection adjusted by age, hydatid cyst fertility and Echinococcus granulosus genotype Abbreviation: $\mathrm{Cl}$ confidence interval

mainly located in the liver, whereas when $F$. hepatica was present, small cysts were found in a larger proportion in the lungs only. Small cysts may represent either immature cysts that could develop into fertile or infertile cysts, or they could be non-viable cysts.

As reported in other studies, we found that cyst fertility significantly varied in different organs $[11,15,29,40]$, with more fertile cysts in the lungs than in other locations. No statistical association was found between cyst type and age or co-infection with $F$. hepatica, analyzed independently. However, in older cattle there was an association between cyst type and co-infection with $F$. hepatica. In the presence of the latter, there were more animals with infertile cysts and fewer with small cysts than in single infections.

Cattle cyst fertility reported in this study, is similar to that reported by other authors $[11,15]$, but noticeably lower than in other studies [13, 18, 33, 34, 41]. Literature data suggest that polyparasitism interactions can alter the site in host used by the parasites. For example, the antagonic relationship between Moniliformis moniliformis and Hymenolepis diminuta, in which when both parasites co-infect the gut of rats, $M$. moniliformis is able to displace $H$. diminuta to a less nutrient rich site in the small intestine; this antagonic relationship was host-specific [1]. The fact that there are different viscera affected when both F. hepatica and E. granulosus (s.l.) parasitize the same bovine host could be an example of an antagonic relationship, since the liver is the main organ or site in host that both parasites seek to establish themselves. The mechanisms that could explain how $F$. hepatica infection can affect the parasitized viscera by E. granulosus (s.l.) remains to be studied, since it could be via immune response modulation or merely the physical condition of the liver tissue after $F$. hepatica infection that makes it unsuitable for E. granulosus (s.l.) to establish. This could also be a factor that contributes to the low cyst fertility in cattle from Chile, since the liver is usually infected with $F$. hepatica. One of the limitations of our study is that we worked with natural infections, so we cannot determine the temporality of $F$. hepatica and E. granulosus infection in cattle, but here we have shown an effect of displacing the hydatid cysts toward the lungs and an increased proportion of small cysts associated with co-infection with $F$. hepatica.

\section{Conclusions}

Cattle naturally co-infected with E. granulosus and $F$. hepatica have a lower chance of presenting hydatid cysts in the liver with an increased chance for lung cyst localization, especially for smaller hydatid cysts, suggesting that $F$. hepatica may affect the instate of E. granulosus in the liver. These results suggest that in cattle natural infected with $E$. granulosus and $F$. hepatica, both parasites display an antagonistic relationship.

\section{Funding}

Funding was provided by FONDECYT-Chile No. 1161475 and the Universidad Andres Bello internal project DI-1249-16/RG. The funding bodies had no role in the design of the study, the collection, analysis and interpretation of data, or in writing the manuscript.

\section{Availability of data and materials}

All data generated or analyzed during this study are included in this published article.

\section{Authors' contributions}

CS participated in the sample and data collection, analyzed the obtained data and wrote most of the initial draft of the manuscript. CA participated in the sample and data collection and initial data analysis. $\mathrm{CH}$ participated in data analysis, wrote part of manuscript and provided critical review of the manuscript. FC acquired samples and provided critical review of the manuscript. MJ acquired samples. MH provided assistance with the statistical analysis of the results. RP did the study design, results analysis and was a major contributor in writing the manuscript. All authors read and approved the final manuscript.

\section{Ethics approval}

All procedures were approved by the Universidad Andres Bello Bioethics Board (protocol number 016/2016).

\section{Consent for publication}

Not applicable.

\section{Competing interests}

The authors declare that they have no competing interests.

\section{Publisher's Note}

Springer Nature remains neutral with regard to jurisdictional claims in published maps and institutional affiliations.

\section{Author details}

${ }^{1}$ Escuela de Medicina Veterinaria, Facultad de Ciencias de la Vida, Universidad Andres Bello, Santiago, Chile. 'Laboratorio de Biología Periodontal, Facultad de Odontología, Universidad de Chile, Santiago, Chile. ${ }^{3}$ Facultad de Ciencias de la Salud, Universidad Autonoma de Chile, Santiago, Chile.

Received: 26 April 2018 Accepted: 30 September 2018

Published online: 10 October 2018

\section{References}

1. Behnke JM. Structure in parasite component communities in wild rodents: predictability, stability, associations and interactions .... or pure randomness? Parasitology. 2008;135:751-66.

2. Blackwell AD, Martin M, Kaplan H, Gurven M. Antagonism between two intestinal parasites in humans: the importance of co-infection for infection risk and recovery dynamics. Proc Biol Sci. 2013;280:20131671.

3. Moreau E, Chauvin A. Immunity against helminths: interactions with the host and the intercurrent infections. J Biomed Biotechnol. 2010;2010:428593.

4. Romig T, Deplazes P, Jenkins D, Giraudoux P, Massolo A, Craig PS, et al. Ecology and life cycle patterns of Echinococcus species. Adv Parasitol. 2017; 95:213-314.

5. Agudelo Higuita NI, Brunetti E, McCloskey C. Cystic echinococcosis. J Clin Microbiol. 2016;54:518-23. 
6. Wuhrer M, Grimm C, Dennis RD, Idris MA, Geyer R. The parasitic trematode Fasciola hepatica exhibits mammalian-type glycolipids as well as Gal(beta16)Gal-terminating glycolipids that account for cestode serological crossreactivity. Glycobiology. 2004;14:115-26.

7. Cucher MA, Macchiaroli N, Baldi G, Camicia F, Prada L, Maldonado L, et al. Cystic echinococcosis in South America: systematic review of species and genotypes of Echinococcus granulosus sensu lato in humans and natural domestic hosts. Trop Med Int Health. 2016:21:166-75.

8. Riesle S, Garcia MP, Hidalgo C, Galanti N, Saenz L, Paredes R. Bovine lgG subclasses and fertility of Echinococcus granulosus hydatid cysts. Vet Parasitol. 2014:205:125-33.

9. Paredes R, Godoy P, Rodriguez B, Garcia MP, Cabezon C, Cabrera G, et al. Bovine (Bos taurus) humoral immune response against Echinococcus granulosus and hydatid cyst infertility. J Cell Biochem. 2011;112:189-99.

10. Paredes R, Jimenez V, Cabrera G, Iraguen D, Galanti N. Apoptosis as a possible mechanism of infertility in Echinococcus granulosus hydatid cysts. J Cell Biochem. 2007;100:1200-9.

11. Addy F, Alakonya A, Wamae N, Magambo J, Mbae C, Mulinge E, et al. Prevalence and diversity of cystic echinococcosis in livestock in Maasailand, Kenya. Parasitol Res. 2012;111:2289-94.

12. Al Kitani FA, Al Riyami S, Al Yahyai S, Al Rawahi AH, Al Maawali M, Hussain $\mathrm{MH}$. Abattoir based surveillance of cystic echinococcosis (CE) in the Sultanate of Oman during 2010-2013. Vet Parasitol. 2015;211:208-15.

13. Andresiuk MV, Gordo FP, Saarma M, Elissondo MC, Taraborelli A, Casalongue C, et al. Echinococcus granulosus genotype G1 dominated in cattle and sheep during 2003-2006 in Buenos Aires Province, an endemic area for cystic echinococcosis in Argentina. Acta Trop. 2013;127:136-42.

14. Balbinotti H, Santos GB, Badaraco J, Arend AC, Graichen DÂS, Haag KL, et al. Echinococcus ortleppi (G5) and Echinococcus granulosus sensu stricto (G1) loads in cattle from southern Brazil. Vet Parasitol. 2012;188:255-60.

15. Daryani A, Sharif $M$, Amouei A, Nasrolahei M. Fertility and viability rates of hydatid cysts in slaughtered animals in the Mazandaran Province, northern Iran. Trop Anim Health Prod. 2009;41:1701-5.

16. Founta A, Chliounakis S, Antoniadou Sotiriadou K, Koidou M, Bampidis V. Prevalence of hydatidosis and fertility of hydatid cysts in food animals in northern Greece. Vet Ital. 2016;52:123-7.

17. Kamelli M, Borji H, Naghibi A. Genetic identification of cattle hydatid cyst isolates from northeast and southwest of Iran. Ann Parasitol. 2016:62:301-5.

18. Latif AA, Tanveer A, Maqbool A, Siddiqi N, Kyaw-Tanner M, Traub RJ. Morphological and molecular characterisation of Echinococcus granulosus in livestock and humans in Punjab, Pakistan. Vet Parasitol. 2010;170:44-9.

19. Thapa NK, Armua-Fernandez MT, Kinzang D, Gurung RB, Wangdi P, Deplazes P. Detection of Echinococcus granulosus and Echinococcus ortleppi in Bhutan. Parasitol Int. 2017;66:139-41.

20. Gonzalez H, Plaza J, Abalos P. Fertilidad del quiste hidatídico en tres especies animales en Chile y estudio de la vitalidad de sus escólices. Bol Chil Parasitol. 1981;1-2:14-9.

21. Poglayen G, Varcasia A, Pipia AP, Tamponi C, Parigi M, Marchesi B, et al. Retrospective study on cystic echinococcosis in cattle of Italy. Infect Dev Ctries. 2017;11:719-26.

22. Scala A, Bosco A, Pipia AP, Tamponi C, Musella V, Costanzo N, et al. Cystic echinococcosis in cattle dairy farms: spatial distribution and epidemiological dynamics. Geospat Health. 2017;12:562.

23. Abdel-Rahman EH, Abdel-Megeed KN, Abuel-Ezz NM. Cross-reaction: a common trait among helminthes. J Egypt Soc Parasitol. 2003;33:457-71.

24. Talaat RM, Ali NM, Elwakil HS. Impact of Schistosoma mansoni and Echinococcus granulosus experimental coinfection on interleukin 10 and interferon gamma cytokines profile. Exp Parasitol. 2013;134:474-81.

25. Galindo M, Schadebrodt G, Galanti N. Echinococcus granulosus: cellular territories and morphological regions in mature protoscoleces. Exp Parasitol. 2008;119:524-33.

26. Correa F, Stoore C, Horlacher P, Jimenez M, Hidalgo C, Alvarez Rojas CA, et al. First description of Echinococcus ortleppi and cystic echinococcosis infection status in Chile. PLoS One. 2018;13:e0197620.

27. Morales MA, Luengo J, Vasquez J. Distribución y tendencia de la fasciolosis en ganado de abasto en Chile, 1989-1995. Parasitol Día. 2000;24:115-8.

28. Luengo J, Olivares M. Causales de decomiso en bovinos beneficiados en mataderos de Chile. Av Cien Vet. 1995;10:1.

29. Negash K, Beyene D, Kumsa B. Cystic echinococcosis in cattle slaughtered at Shashemanne Municipal Abattoir, south central Oromia, Ethiopia: prevalence, cyst distribution and fertility. Trans R Soc Trop Med Hyg. 2013;107:229-34.
30. Rinaldi L, Maurelli MP, Veneziano V, Capuano F, Perugini AG, Cringoli S. The role of cattle in the epidemiology of Echinococcus granulosus in an endemic area of southern Italy. Parasitol Res. 2008;103:175-9.

31. Craig PS, Hegglin D, Lightowlers MW, Torgerson PR, Wang Q. Echinococcosis: control and prevention. Adv Parasitol. 2017;96:55-158.

32. Innocent GT, Gilbert L, Jones EO, McLeod JE, Gunn G, McKendrick IJ, et al. Combining slaughterhouse surveillance data with cattle tracing scheme and environmental data to quantify environmental risk factors for liver fluke in cattle. Front Vet Sci. 2017:4:65.

33. Kebede W, Hagos A, Girma Z, Lobago F. Echinococcosis/hydatidosis: its prevalence, economic and public health significance in Tigray region, North Ethiopia. Trop Anim Health Prod. 2008;41:865-71.

34. Pednekar RP, Gatne ML, Thompson RCA, Traub RJ. Molecular and morphological characterisation of Echinococcus from food producing animals in India. Vet Parasitol. 2009:165:58-65.

35. Ibrahim MM. Study of cystic echinococcosis in slaughtered animals in Al Baha region, Saudi Arabia: interaction between some biotic and abiotic factors. Acta Trop. 2010;113:26-33.

36. Acosta-Jamett G, Cleaveland S, Cunningham AA. Bronsvoort BMd, Craig PS. Echinococcus granulosus infection in humans and livestock in the Coquimbo region, north-central Chile. Vet Parasitol. 2010;169:102-10.

37. Alvarez Rojas CA, Romig T, Lightowlers MW. Echinococcus granulosus sensu lato genotypes infecting humans - review of current knowledge. Int J Parasitol. 2014;44:9-18.

38. Brehm KK. U. Echinococcus-host interactions at cellular and molecular levels. Adv Parasitol. 2017:95:147-212

39. Sohair IB, Eman MN. Histopathological and bacteriological studies on livers affected with fascioliasis in cattle. Egypt J Comp Path Clinic Path. 2009;22: $19-45$.

40. Mitrea IL, Ionita M, Costin II, Predoi G, Avram E, Rinaldi L, et al. Occurrence and genetic characterization of Echinococcus granulosus in naturally infected adult sheep and cattle in Romania. Vet Parasitol. 2014;206:159-66.

41. Ernest $E$, Nonga HE, Kassuku AA, Kazwala RR. Hydatidosis of slaughtered animals in Ngorongoro district of Arusha region, Tanzania. Trop Anim Health Prod. 2008:41:1179-85.

\section{Ready to submit your research? Choose BMC and benefit from:}

- fast, convenient online submission

- thorough peer review by experienced researchers in your field

- rapid publication on acceptance

- support for research data, including large and complex data types

- gold Open Access which fosters wider collaboration and increased citations

- maximum visibility for your research: over $100 \mathrm{M}$ website views per year

At $\mathrm{BMC}$, research is always in progress.

Learn more biomedcentral.com/submissions 